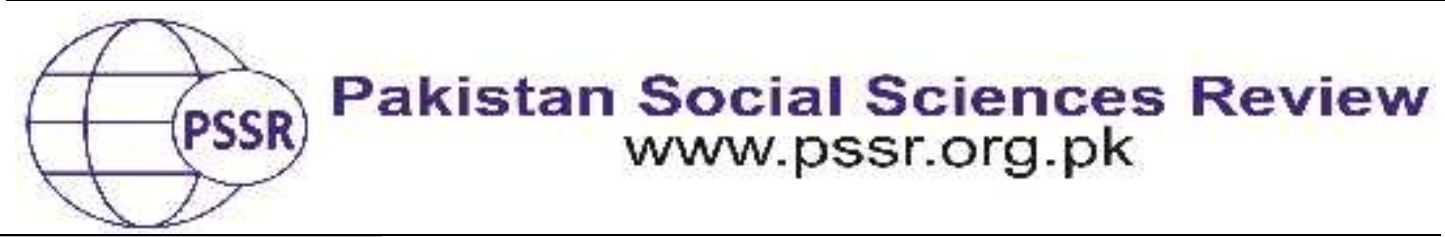

RESEARCH PAPER

\title{
Opinion of the Female Voters Regarding Female Deprivation of Vote Casting in Southern Punjab, Pakistan
}

\author{
Imran jamil ${ }^{1}$ Dr. Kausar Parveen ${ }^{2}$ Amir Jamil ${ }^{3}$
}

1. Ph. D Scholar Department of Sociology University of Karachi, Pakistan

2. Associate professor Department of Sociology University of Karachi, Pakistan

3. Ph. D. Scholar Area Study centre Quaid-e-Azam University Islamabad, Pakistan

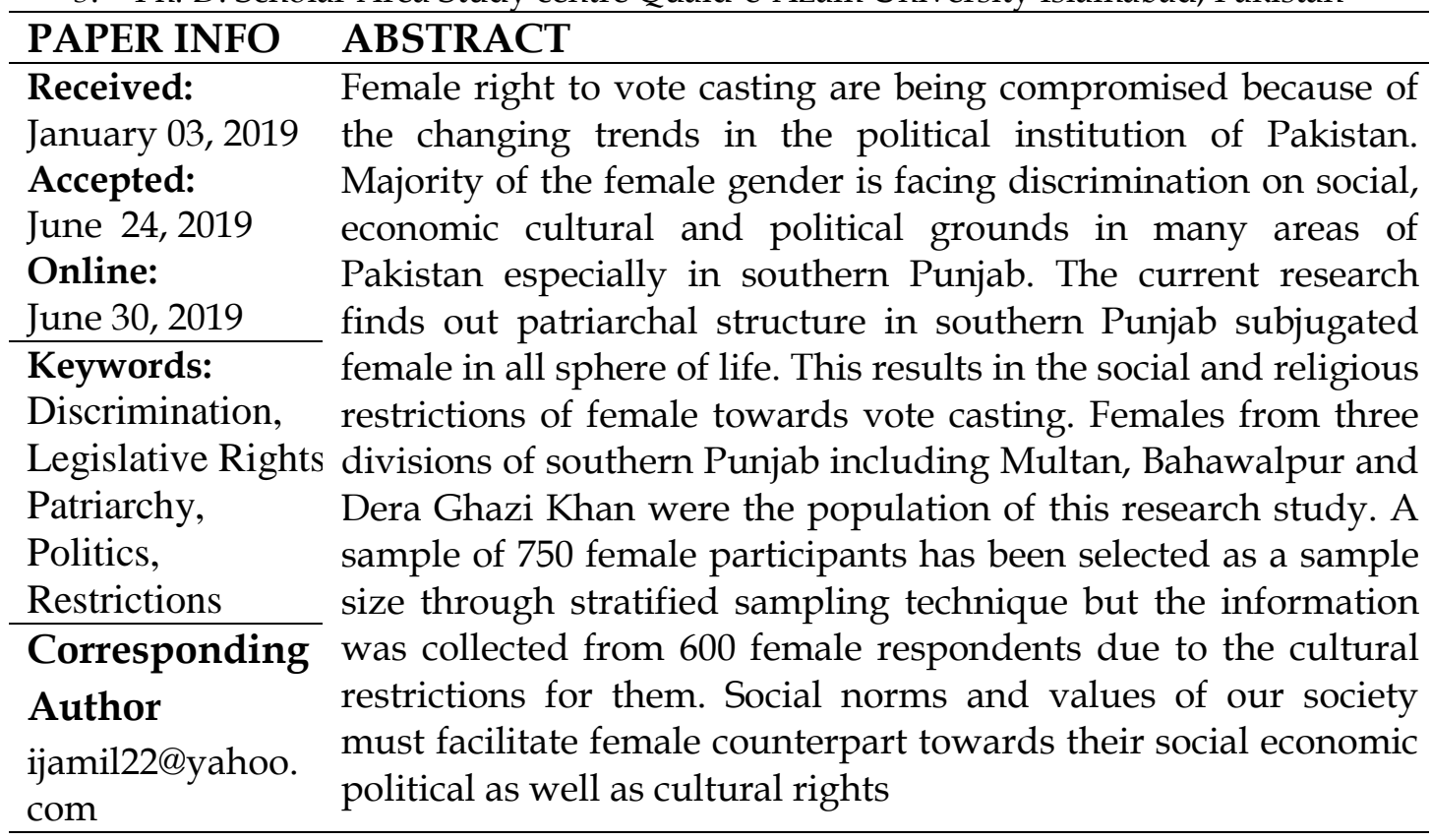

\section{Introduction}

Southern Punjab is a multilingual and multicultural zone having colours of three variant customs such as Saraiki, Punjabi and Balochi. Majority population is pre-dominantly Saraiki to the breed standards are utmost importance. More than half of the population of southern Punjab belongs to village life. Old ways of living, customs and rituals are being practised by the people living in rural areas. Their situation cannot be expressed in words. Similarly geographical and ecological factors lead to the customs of society. The population is largely illiterate and poverty is the destiny of the masses, even the younger generation who joined the schools and have passed out from there doesn't dare to use in other cities. They are facing many socioeconomic challenges especially the female gender. Even feudalism and patriarchal structure is being quietly practised in southern Punjab now-a- days. On the other hand culture of southern Punjab is male centurial, due to this reason female gender 
tend to be second in command. Spiritual mindedness, ethnicity and civilization have been utilised as an alarming purpose. But these causes or reasons are not supported or strengthen by any ordinance or even not a single act has been passed what maintain patriarchal system along with promoting secondary or inferior position of females. It is cleared now and kept up abbreviation among people towards division of labour and segmented or divide beneficial resources within sphere of morality. Incorporate the major problems of the government particularly in the area of casting vote. Policy makers also need margins for making new discussions and conversations which ensure effective and vital women contributions toward legislative equality between both genders in the region (Mubashir \& Sultan, 1999).

In every democratic system elections plays the role as a centre piece to demonstrate effectively in all important respects and gives a chance to find, begin or present amenable governance. Apart from the leadership it also manifests uniformity among people through vote casting on the basis of one group resident. Such practices also build-up as a nation in democratic countries all over the world, Moreover the government cannot be flourish unless basic rights regarding politics given to the people of common society to work decently, through strengthening the individual (Bratton \& Mattes, 2001).

On the other hand the concept of political rights for women in Islam emerged fourteen hundred years ago. If we throwback to our history of Islam, women have contributed a vital part in regarding political matters. Islam designated basic rights to women throughout its history, the last address of the Holy Prophet (P.B.U.H) clearly specify the role for both male and female as well as the rights too. In Islam not only equal rights have been given to both male and female regarding nominations in legislative structure but also emphasized on protection of female political rights too (Alam, 2004).

\section{Literature Review}

Rights and privileges which women defend for themselves worldwide are called women rights. The foundation for the rights of women was established in 19th century and movement of feminism was started in 20th century. Many countries support women rights by law, local custom and by showing their behaviour towards this ideology, while on the other hand they are also being disregarded and repressed too (McElroy \& Marsh, 2010).

Where the rights had been ignored or threatened, there, many issues had also been arise too with the idea or opinion regarding women rights. These issues include right to vote, to hold public office, or to be a part in legal contracts are the major issues. But due to its solid position, women are also supposed to have political rights too. Previous literature supported that woman political rights are real and have equivalent chance of being participated in the political parties through casting votes, or being appointed on the bases of fixed merit (Becker \& Mulligan, 1999). 
Although some improvements were made but large criticism and objection have been made regarding the legal and political rights of women till the end of $18^{\text {th }}$ century. The major problem and criticism was regarding the vote that women should not be given. Then the $19^{\text {th }}$ century is considered to be revolutionary period in which the female movement became the centre of attention in campaign conducted for female suffrage. The aim of this movement was to provide realisation that women should also have right to being vote. Marry Wollstonecraft and Lucretia Mott, known to be prime movers for women rights and campaign regarding feminism. Wollstonecraft said that if men can fulfil his duties to the family too, then why women could not be supposed to play their role to the state (Cole, 1994).

Filer and Lawrence stated that women have equal chance to be a part of political process because it directly changes their lives. Means by getting dominant position or be a political leader, women always become socially, financially and morally strong and secured as well .Countries which are enriched with equal women contribution and women have authority in civil, society and political forum, these countries always be prone to or aimed to be inclusive, show responsible attitude toward any task, unbiased and sense of equity follows throughout the nation and autonomous environment might be established in that countries (Filer \& Lawrence, 1991).

In addition to this, it has also been examined by Hosken, Fran P in 1981that participation of women in peace campaign leads to positive results. Their presence can enhance the scope of agreement and the probability of targeted peace can also be upgraded. Despite of its benefits, all over the world women are still mainly missing from national and local decision making areas. Women are less than $20 \%$ of the world legislation. Due to lack of support and asserts they faced many barriers to be a part of civic and political bodies (Gerber \&Donald, 2004).

Moreover in the favour of women equal political participation, The UNDP strategic plan and its gender equality strategy presented through the years of 2014 to 17 gave priority and importance to women participation regarding making decision and in giving authority to them as well. Not only this it also motivate and help countries to administer international, regional and national commitment regarding women contribution and involvement in decision making. The main objectives of UNDP plan is to open the door for women to get chances and give provide pathway through which they can utilize their calibre regarding political rights and also provide chances to take part in decision making and play key role in political process. This strategy also motivates or support the utilisation of Temporary Special Measure, that includes women hood quotas, this helps in enhancing the position and stability of women regarding equal participation and taking decision in important matters (Gardner, 1993).

Moreover UNDP worked together with networks and platforms that are in the favour of women political right including United Nation Women, United Nation 
Department of Political Affairs, Office of High Commissioner for Human Rights, United Nations International Children's Education Fund and inter-state institutions such as Organisation for Security and Co-operation in Europe and Centre for Social Organisation of Schools working on female legislative contribution, incorporate with Individuals with Disabilities Education Improvement Act ,United State Institute of Peace and Interpeace, along with geographical and internal CSOs (ADB, 2004).

Furthermore in favour to women political rights, the Inter Parliamentary Union stated in 1992 that the idea of democracy will only get true and vital importance when political rules and national laws are decided by both gender equally and having the regard for the likings and aptitude of both halves of the population.So to conclude as we have noticed that much work and efforts have been done to promote the women political rights. So to add in this, Pakistan is also one of the countries who always take part in promoting the positive work and take initiative steps regarding in any field. So as other countries admit and admire the skills and capabilities of women in the area of politics, in the same way Pakistan also in favour and hence give chance to women to be a part of political house and appointed candidates through proper and in systematic manner. Hence in Pakistan under the supervision of first female Speaker of the National Assembly, the first ever bipartisan Caucus of women Parliamentarian has allowed its workers to work together for the reasons of women in Pakistan. Through it kerosene burn victims, survivors of violence all are being centre of attention. In short its objective les behind the empowerment of women and it all possible because women got dominant position in political area (McGeorge, 2006)

\section{Material and Methods}

Structured or well planned procedure not only explores truths but also verified that truths are called social research. In addition to this, social research also involves chain of inter relationship, making assumptions regarding the explanation of any phenomena as well as native laws that govern them (Nelson and Wright, 1995). Many experts are facing issues regarding evaluation, methodological techniques and in different ways of assessment or observing the behaviour which is really supreme to study human social behaviour under sociological perspective (Olson, 2001). Purpose of present research study is to explicate basic instruments as well as and approaches which has been used to gather the required information. Females as a target population have been recruited from the cities of southern Punjab i.e. Multan, Dera Ghazi Khan and Bahawalpur. 750 participants had been decided to take as a representative sample of a study through multi-stage procedure. Rajanpur, Sadiqabad, Dera Ghazi Khan as well as Vehari zone has been preferred purposively because these districts have reported the maximum number of women political rights violation in recent times. Data was collected through raw and other resources. Initial information was collected by conversation or discussion with participants and surveys, Government reports, Non-governmental organization reports who are working on specifically women rights issues were collected as 
secondary source for the completion of this research. Questions were designed to evaluate the possible socio-economic as well as cultural challenges that are responsible for political rights exploitation of women as a voter in southern Punjab. The first portion of the interview schedule addressed various demographic and structural questions pertaining to female. The second portion addressed various socio-economic, political and cultural challenges faced by women in southern Punjab while the last portion focused the determinants of policy failure regarding female voters, the role of media and NGO's. The researcher compared different responses on pre-coded five point likert scale. Both structured and unstructured questions were used to get maximum response. The data was coded by using the Statistical Package of Social Sciences (Russell \& Colm, 2003). At the end ANOVA test has been utilized to measure the feedback or opinion of female. Basic value was calculated by the researcher for more than five variables including socio-economic status of women, cultural domain, Male dominancy, conservative attitude of the family etc. $\mathrm{P}$ value validated that alternate hypotheses is accepted as there is momentous difference among the opinion of all female respondents.

\section{Results and Discussion}

Table No. 1

Division of percentage among participants regarding socio-economic along with cultural limitations

\section{Socio-economic, Political and cultural constraints}

Division of percentage belonged to participants relating to their opinion

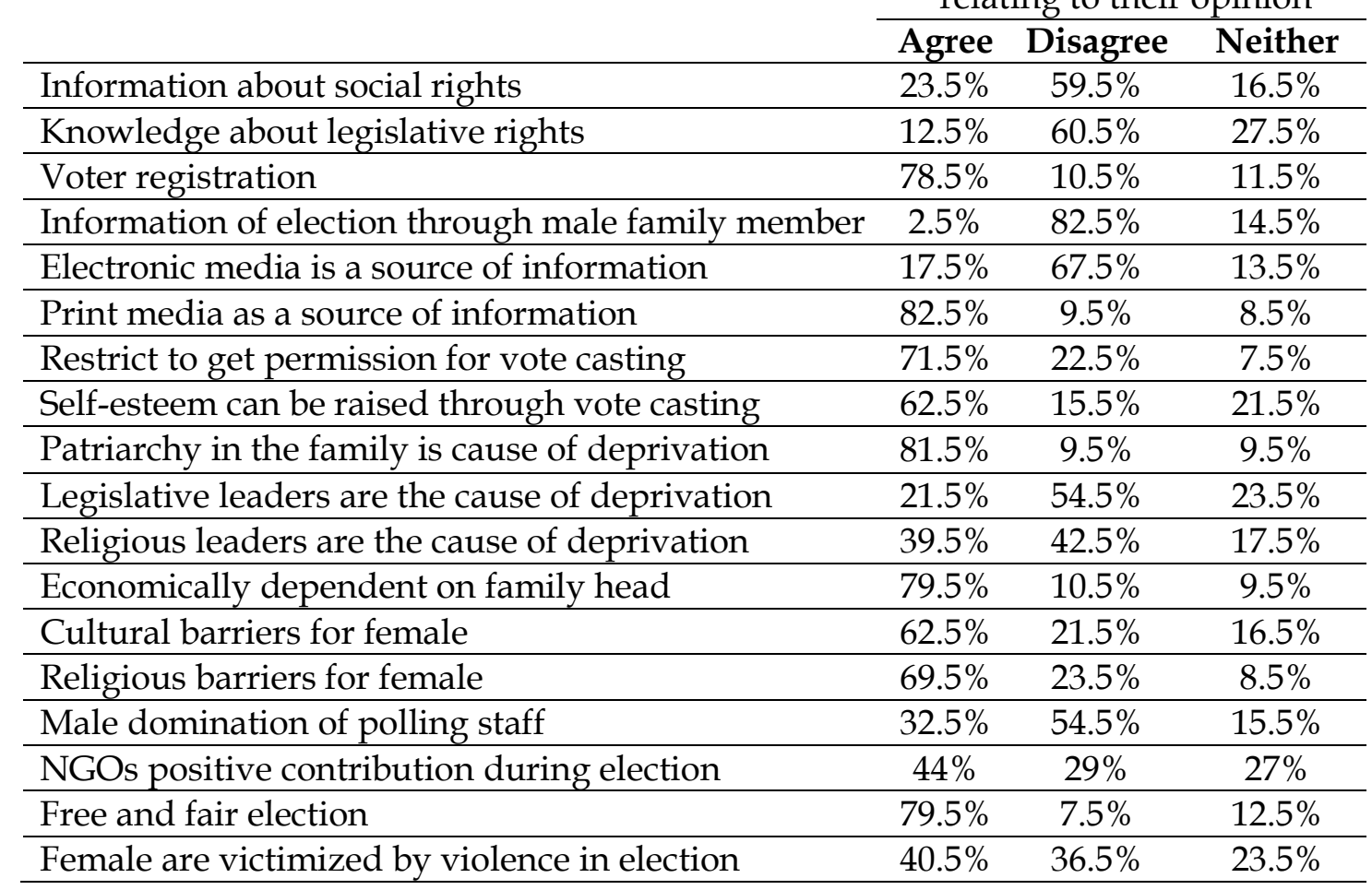


$\begin{array}{llll}\text { Government play key role in encouraging female } & 71 \% & 20 \% & 09 \%\end{array}$ Discussion

Women from southern Punjab are deprived of their political rights due to the conventional assertiveness of the male head of the family not only in rural areas but also in the urban areas because women are dependent on their male family members. This table shows that $23.5 \%$ of the women agree on the knowledge about their social and political rights while rest of the others were totally disagree. Knowledge about social, political and cultural rights always come through education and the literacy rate of the study area is very low as compared to western part of Punjab. It is also identified from the opinion of the female respondents that $60 \%$ of women have registered their vote while rest of the others don't about the vote registration process, that's why they always used to deprive from their political right in terms of vote casting as compared to men. When the question was asked about the participation of women in political assemblies and processions $82.5 \%$ of the respondents denied because of their cultural restrictions. While rest of the others have mixed response on their participation. The table also clarified that $17.5 \%$ of women agreed that electronic media is the only source for them to get information about the election. While rest of the others get information about election from their male counterpart. Normally we live in male oriented society where the leader of family is male, so due to this patriarchal system $71.5 \%$ of the respondents agreed that women have always restrictions to get permission for casting their votes, while rest of the others can cast their or participate in election without any restrictions. Another factor of the women political rights deprivation is that preference given to male in every walk of life as compare to women on socio-economic, cultural and political rights. Alternatively $81.5 \%$ of the respondents agree that patriarchal system not only in society but also within blood relation becomes a major reason that act as a barrier for females regarding their legislative authority. The above table pop up this standpoint that $21.5 \%$ of the respondents agree that religious leaders as well as political leaders of southern Punjab are the major elements for their political rights deprivation toward vote casting. On the other hand $79.5 \%$ of the respondents agree that male head of their families are responsible for their political rights deprivation.

Table No 2

\begin{tabular}{|c|c|c|c|c|}
\hline \multicolumn{5}{|c|}{ H1: Higher will be the education higher will be the rights to women } \\
\hline Source & DF & MS & SS & \multirow{4}{*}{$\begin{array}{c}F \\
25.91\end{array}$} \\
\hline Factors & 2 & 41.92 & 79.88 & \\
\hline Errors & 598 & 2.34 & 675.1 & \\
\hline Total & 600 & & 754.82 & \\
\hline \multicolumn{5}{|c|}{ H2: More social obstruction decreases will be female political participation } \\
\hline Source & DF & MS & SS & \\
\hline Factors & 2 & 109.29 & 218.57 & \\
\hline Errors & 598 & 1.45 & 871.82 & $F$ \\
\hline Total & 600 & & 1090.40 & 73.84 \\
\hline
\end{tabular}




\begin{tabular}{|c|c|c|c|c|}
\hline Source & DF & MS & SS & \multirow{4}{*}{$\begin{array}{c}F \\
69.37\end{array}$} \\
\hline Factors & 2 & 112.80 & 225.61 & \\
\hline Errors & 598 & 1.62 & 970.86 & \\
\hline Total & 600 & & 1196.47 & \\
\hline \multicolumn{5}{|c|}{$\begin{array}{l}\text { H4: Higher family influence toward religion leads little female liberty to cast their } \\
\text { votes }\end{array}$} \\
\hline Source & DF & MS & SS & \multirow{4}{*}{$\begin{array}{c}F \\
24.13\end{array}$} \\
\hline Factors & 2 & 47.18 & 96.37 & \\
\hline Errors & 598 & 2.93 & 675.01 & \\
\hline Total & 600 & & 1196.47 & \\
\hline \multicolumn{5}{|c|}{ H5: Greater male dominancy leads toward decreased female emancipation } \\
\hline Source & DF & MS & SS & \multirow{4}{*}{$\begin{array}{c}F \\
27.91\end{array}$} \\
\hline Factors & 2 & 40.97 & 81.84 & \\
\hline Errors & 598 & 1.27 & 876.01 & \\
\hline Total & 600 & & 957.82 & \\
\hline \multicolumn{5}{|c|}{ H6: Higher role of media shows greater tendency to cast votes among females } \\
\hline Source & DF & MS & SS & \multirow{4}{*}{$\begin{array}{c}F \\
93.17\end{array}$} \\
\hline Factors & 2 & 130.15 & 262.29 & \\
\hline Errors & 598 & 1.42 & 840.37 & \\
\hline Total & 600 & & 1102.66 & \\
\hline
\end{tabular}

In many regions of Pakistan particularly in southern Punjab, women have limited access to participate in legislative body and cast their votes. Therefore they are always at the receiving end. Political rights alone cannot safe women from not participating in political sphere but also these rights can play an effective role toward women empowerment in Social as well as economic matters (Mubashir, 2000). Awareness should be given to women in this male centric society so that they can be able to be a part of Pakistani politics as a voter and also as a candidate. Many impediments associated with women political rights can keep away when women get equal chance of participation in all sphere of life including their socio-economic, cultural and political matters (Richard, 2000). Due to the equal participation, women can better utilize their abilities and skills in making remarkable change in their status in all aspect of life. On the other hand it is examined that legislative representation of females towards vote casting decreased or becomes lessen just due to the particular group of individuals that's why in the $21^{\text {st }}$ century women from southern Punjab still struggling for their fundamental rights (Shachar \& Nalebuff, 1999). It is the responsibility of the government to rephrase its policies and implement those policies from grass root level so that the women from rural and sub-urban areas can enjoy their basic rights without any restrictions.

\section{Conclusion}

The main theme of present research was to explore the perspective of women as well as their blood relations toward casting their votes. Different opinions have been collected from women regarding inclination toward female emancipation in the 
fields of casting their votes and enrolment of voters as well. So in result pragmatic behaviour and enthusiastic family practises have been recorded. Knowledge, information and mindfulness plays an essential role in changing the frame of mind regarding problems related to males and females.In addition to this, it has also been recorded that pragmatic and optimistic attitude of people towards vote practising as well as enrolment of voters too, just for the sake of man's own interest to promote the required or well liked individual. Moreover negative behaviour was shown by participants when they were questioned about making conclusions concerning job and legislative involvement. It has been described by participants that they were not in the favour of females to make commitments regarding job due to bad conditionof work place areas and secondly above mentioned fields are supposed to be male oriented areas which are not suitable for women to work. Hence it shows the pure male dominant culture in our homeland Pakistan spreading its reflection in southern Punjab as well. Furthermore as it is explained earlier that lack of knowledge becomes the major hurdle in women empowerment so as a result, it has been reported that maximum proportion of individuals are not in favour of electoral structure because this activity is considered to be as resistant or opposed to Islamic values.

Hence with the passage of time, opinions, behaviour or thoughts of people in Pakistan tend to be transitory, but patriarchal system plays a crucial role in limiting or regulating the practices of women empowerment to some extent. Furthermore, many campaigns, movements and work are in progress that not only aim to support women empowerment but they also have objective to modify rigid school of thoughts that people hold for women empowerment in relation to vote casting etc. So to conclude, we all know that variation takes place step by step in the social circumstances, in the same way contribution of women in legislative structure cannot be spontaneously changed; it also requires some time to be a part of existing lifestyle. But in the present era unfortunately it is not in stable condition. 


\section{References}

Alam, M. (2004). New Local Government Reforms in Pakistan-A way Forward towards Inducing Social Change, UK: School of Public Policy, University of Birmingham.

ADB, (2004). Gender and Governance Issues in Local Government-Regional Report of Technical Assistance in Bangladesh, Nepal, Pakistan, Asian Development Bank, Manila.

Bratton, M., \& Mattes, R. (2001). Support for Democracy in Africa: Intrinsic or Instrumental? British Journal of Political Science,31(3), 447-474.

Becker, G.S. \& Mulligan, C.B. (1999). Is voting rational or instrumental? Working paper, University of Chicago.

Cole, E. R. (1994). A struggle that continues: Black women community and resistance. In C. Franz \&A. J. Stewart (Eds.), Women creating lives: Identities, resilience, and resistance (pp. 309-324). Boulder, CO: West view.

Filer, John E., Lawrence W. Kenny, and Rebecca B. Morton. (1991). "Voting Laws, Educational Policies, and Minority Turnout." Journal of Law and Economics pp: 371-93.

Filer, John E. \& Lawrence W. Kenny. (1980). Voter Turnout and the Benefits of Voting. Public Choice pp: 575-85.

Gerber, Alan S. \& Donald P. Green. (2004). Get Out the Vote: How to Increase Voter Turnout, Brookings Institution Press: Washington, DC.

Gardner, James A. (1993). The Ambiguity of Legal Dreams: A Communitarian Defense of Judicial Restraint7, 1 N.C. L. REV8. 05

J. O'Connor \& E. F. Robertson. (2005). voting"'. The Mac Tutor History of Mathematics Archive. Retrieved.

Kristina, M. (2009). Women in Roman Historiography, Cambridge University Press, p. 278

Morsink, Johannes, (1999). The Universal Declaration of Human Rights: origins, drafting, and intent. University of Pennsylvania Press.ISBN 978-0-8122-17476

McGeorge S. (2006). Status and patronage, French political History: The High Empire, A.D. 70-192 University of Paris Press, p. 18.

McElroy, G., \& Marsh, M. (2010). Candidate Gender and Voter Choice: Analysis from a Multimember Preferential Voting System. Political Research Quarterly,63(4), 822-833. 
Mubashir, A. Syed. (2000). Gender and Health Care Utilization in Pakistan. The Pakistan Development Review, 39(3), 213-234.

Mubashir \& Sultan, (1999). socio-cultural constraints and women's decision making power regarding reproductive behavior, The Pakistan development Review 38:4; 689696.

Nelson, N. \& Wright S. (1995). Power and participatory development. Theory and practice, London: ITDG Publishing

Olson E. E., \& Eoyang G.H. (2001). Facilitating Organization Change. Lessons from Complexity Science, San Francisco: Jossey-Bass/Pfeiffer,

Russell \& Colm O' Cinneide. (2003). Source: The International and Comparative Law Quarterly, Vol. 52, No. 3 pp. 587-614Published by: Cambridge University Press on behalf of the British Institute of International and Comparative Law.

Russet, Bruce, M. (1964). World Handbook of Social and Political Indicators, New Haven and London, Yale Univ. Press, 373 pp.

Reason P, \& Bradbury H. (2001). Action Research. Participative Inquiry \& Practice, London: SAGE Publications

Richard, S. (2000). Status and patronag", Cambridge Ancient History: The High Empire, A.D. 70-192 Cambridge University Press, p. 18.

Shachar \& Nalebuff, (1999). Follow the leader; Theory and Evidence on political participation, An American Economic Review, 89(3): 525-547. 